\title{
GENDER, ENVIRONMENT AND LIVELIHOOD SECURITY: AN ALTERNATIVE VIEWPOINT FROM INDIA
}

\section{Meera Kaul Shah and Parmesh Shah}

\section{INTRODUCTION}

The last decade has seen the emergence of women, environment and development (WED) discourse which has influenced development theory and practice. It projects women as both the main victims of environmental degradation, and as the most appropriate participants in environmental conservation programmes (CSE 1985; Dankelman and Davidson 1988; Davidson 1989). WED is influenced by the ecofeminist school which sees an organic relationship between women and nature (Shiva 1988; Plant 1989; Diamond and Orenstein 1990).

The WED approach has been criticized on various grounds: for focusing solely on women's roles, for assuming a 'special' relationship between women and nature and for falling into essentialism and thus universalizing the experiences of women. The still evolving gender, environment and development (GED) approach attempts to overcome the shortcomings of WED by highlighting the need to understand gender relations as they operate within a given social framework when addressing issues related to sustainable development (Leach 1992; Rocheleau 1991a).

This article studies the relevance and limitations of WED and GED approaches in development practice using a detailed case study. The study draws on the personal experience of the authors while working for an NGO, the Aga Khan Rural Support Programme (AKRSP) in Gujarat state in India.

The main argument of this article is that it is not women alone who are adversely affected by environmental destruction: men and women are both affected, albeit in different ways, when they have traditionally depended on natural resource-based livelihoods. Therefore men may also show concern for environmental protection when their interests are at stake. A singular focus on either men or women and an analysis of their specific roles in isolation from the overall context of gender relations can project images

1 This section has drawn from oral histories narrated by the people and recorded by the authors while working in the area. Since of an artificial equilibrium which is vulnerable and difficult to sustain in the long run.

Importantly, the case study brings out the need to look beyond gender relations as they are generally described in the narrow village community context, to include a consideration of the wider society and inter-village relations and dynamics in natural resource management.

\section{CHANGES IN RESOURCE BASE AND LIVELIHOOD STRATEGIES IN DEDIAPADA AND VALIA, 1940 - 1984}

Dediapada and Valia, two tribal blocks in Bharuch district, are part of one of the most backward and underdeveloped areas in Gujarat. Local people grow one rainfed crop every year, relying heavily on agriculture as their main source of livelihood. Small agricultural holdings, highly undulating land resulting in high rates of top soil erosion, and poor productivity make it necessary for village people to migrate seasonally to the neighbouring prosperous district of Surat in search of alternative livelihoods.

Oral histories ${ }^{1}$ recount that life was not always like this in Dediapada and Valia. These blocks fall in the Rajpipla Forest Division and are known to have had a dense forest cover until about 50 years ago. People recall that before India became independent in 1947 most of the agricultural land in this area belonged to jagirdars (feudal landlords). Village people were able to work the land under share-cropping arrangements where they provided labour and jagirdars provided all other inputs. The produce was shared equally among both parties.

Since the area was rich in natural forests, people could fish, hunt, pick fruit and other food to meet their subsistence requirements. Forests were also a source of other minor forest produce useful for building huts, making implements and meeting fuel and fodder requirements.

recorded history was not accessible while writing this article, it has not been possible to verify this information from other sources. 
After independence when land reforms were carried out, ownership of agricultural land was passed to the tiller. Although farmers no longer had to share their agricultural produce with a jagirdar, they had hardly any resources or reserves for purchasing agricultural inputs. Agricultural operations were interrupted and, in the process, 'outsiders' (i.e. non tribals) and the erstwhile jagirdars filled the gap by taking on the role of money lenders.

Around the same time the Government of Gujarat gave out permits to contractors for clear felling parts of the Rajpipla forest. People recall 1956-57, 1966-67 and $1969-70$ as the main periods when these permits were issued. Initially local people were against the destruction of local forests, although this stand was short-lived due to the problems faced by farmers in sustaining their private agricultural activity and their growing indebtedness. Farmers perceived the opportunity to earn a cash income as more attractive than mortgaging their land to large land owners/ money lenders. Local contractors made wage labour more lucrative in some cases by linking it to the availability of easy credit.

By the early 1970s, the state started to tighten its control over the forests, leaving people without rights to harvest timber. The contractors were also forced to suspend their operations. As a direct result of these changes, men started migrating seasonally to Surat. At this stage, local women recall, there were still enough forests in the area for them to collect sufficient quantities of minor forest produce to use for food (fruit and tubers), fuelwood, fodder, tobacco, medicinal and commercial purposes.

The late 1970s saw a sudden surge in forest felling activities when Forest Labourers Co-operatives were set up by politicians to provide a legal front for the large number of contractors and political middle men to harvest timber in the area. This resulted in both a short-term increase in local employment, and the gradual disappearance of fuel and fodder sources. The Forest Conservation Act came into force in 1980 only after a period of ambiguity when largescale contract deforestation had taken place.

Large-scale deforestation combined with stricter controls over the reserved forest areas, which covered most of the village common lands, increased the vulnerability of people's livelihoods. Men again resorted to migration in large numbers and, this time, some women were forced to join them as well. Apart from the problem of sustaining agricultural production, the forests that had provided the much needed minor produce essential for survival, had now disappeared. People's long-standing relationship with, and dependence on their forest, was thus destroyed in the course of a few years.

The impact of deforestation on the availability of fuelwood and hence on women's lives is clearly expressed in local idioms:

\section{'Khawanu aape pan badtan na aape'}

(When in need, your neighbour will offer you food but no one will give you fuelwood)

\section{'Jay unalo lambesar soti hoi, toe pachchi dukh thai'}

(A woman who sleeps for too long during summer and does not collect enough fuelwood - suffers for the rest of the year)

Although women in these tribal blocks shoulder the major responsibility for fuel and fodder collection, it is not uncommon for men to join in the activity. Men, whenever they own or have access to bullock carts, collect fuel and fodder by cartloads. Men are also responsible for collecting bamboo which is used extensively in construction and making implements.

Environmental degradation has had a deep impact on villagers' lives in Dediapada and Valia. Although women may have felt the impact of environmental degradation more directly, men have also been affected since migration is seen as a last resort, a symbol of destitution.

\section{SUPPORTING A REFORESTATION} PROGRAMME WITH THE PEOPLE 1985 - 1991

It was against this background that the Aga Khan Rural Support Programme (AKRSP) started working in Bharuch district in 1985. AKRSP was set up with the objective of providing an enabling environment for village communities to form village institutions (VIs) for more productive, sustainable and equitable management of their natural resources. In the absence of any ready-made 'model' with which to approach the situation in this area, the organization opted for an action research approach with emphasis on the development of local models of participatory natural resources management. Support was pro vided to VIs for programmes related to both private property resources (PPRs) and common property resources (CPRs). In the case of Dediapada and 
Valia, wastelands development emerged as an important programme focus, since deforested land was the most abundant natural resource in the area.

Although the organization was committed to people's participation from the very beginning, it took time to evolve a suitable approach. The wastelands programme began by locating degraded village common land and consulting local people about reforesting it. Having seen the Government Forest Department (FD) implement a similar programme of social forestry, villagers agreed to the idea since it opened up employment opportunities at the plantation sites. Tree saplings, raised in FD nurseries were planted, and paid guards were employed from among the villagers to protect the newly planted plots for a period of three years. This approach replicated that used by the FD. After some debate on the issue, AKRSP decided to support tree plantation on the deforested 'forest lands' even though it was illegal. The area under the ownership of the FD was classified as reserve forest implying that the villagers were not allowed to plant or harvest trees on this land ${ }^{2}$.

The wasteland programme changed significantly over the years in response to mistakes. Decentralized nurseries for raising saplings were started in every village where the programme was taken up. The process of consulting people about their preferred tree species began in the third year of the programme. This was a response to concerns within AKRSP that although people were participating in activities for short-term benefit, there was no indication that this interest would be sustained. For instance, voluntary protection of reforested lands had not occurred. In fact, similar to the fate of much of the work carried out by the FD, reforested plots were being used for grazing and even harvesting of newly regenerated trees. The survival rates of trees were affected once paid guards were withdrawn from the plots three years after planting.

Since late 1988 participatory rural appraisal (PRA) methods have been used to encourage local people to participate in the planning and appraisal of village level programmes. By 1990 , VIs had taken over the process of planning their areas of priority. In reforestation programmes local people were now involved in locating appropriate plantation sites and selecting preferred tree species. Analysis of tree species preference was carried out with women to ensure that their choices, usually different from men's, were taken into account. The average number of tree species known to villagers was found to be approximately 65-70. Men and women tended to come out with comparable lists which suggests, contrary to popular belief, that men's knowledge of the forests and trees is no less than that of women.

The reforestation programme provided employment and allowed people to accumulate savings. These were held collectively by the VI and used for extending credit to members to undertake soil and water conservation and other upgrading activities on private land. With livelihoods now more secure, people diversified into activities like animal husbandry which benefited from the increased availability of grass for fodder from the protected reforested plots. Seasonal migration dropped considerably and this represented for local people a major improvement in the quality of their lives (Shah 1993).

After a long wait and a great deal of lobbying the Government of Gujarat passed the Joint Forest Management (JFM) resolution in March 1991. Accordingly, VIs participating in protecting the reserved forests could now have a share in the benefits, obtaining rights over minor forest produce (like grass) from the protected area, and also a share in the proceeds from the harvest of mature trees. This change in government attitude was acclaimed as a watershed in the history of forestry development in the country. For VIs in Dediapada and Valia it provided the much needed assurance that people's reforestation efforts would not go unrewarded and this strengthened local resolve to protect the forests.

Voluntary protection became an essential programme component and a condition of AKRSP support. Paid protection disappeared completely. VI members agreed not to enter protected plots, to protect them from grazing animals and fire, and took turns to guard the area in groups. Different VIs developed their own management systems and devised their own processes but, generally, fines or penalties were introduced for members who missed their turn in protection. In some cases facilities like credit and agricultural inputs for PPRs were refused

'The term 'reserved forest' implies that the land is owned by the FD. Forests may not actually exist on that land as much of the forest has already been lost and vast tracks of degraded wastelands lie 'closed' as reserved forests. 
to defaulters. Thus PPR provided leverage to ensure people's participation in protecting their CPRs.

Significantly, however, it was only men who participated in the voluntary protection. ${ }^{3}$

\section{CONDITIONS UNDER WHICH A COMMUNITY DECIDES TO PROTECT ITS ENVIRONMENT}

The Chipko experience has been widely cited in both ecofeminist and WED literature as an example of women's collective effort in conserving their environment. Shiva (1988) uses the example of Chipko to make claims about the 'special' relationship which all women in the third world supposedly enjoy with nature. Women are unproblematically assumed to understand processes of ecological destruction, to have an interest in reversing this degeneration, and thus a role as harbingers of ecological conservation.

Although Shiva mentions that the special relationship Chipko women have with nature arises out of their heavy natural-resource dependence (ibid.: 65), her projections of women as users of natural resources and victims of 'maldevelopment', and as willing ecological conservers, are severed from any analysis of the material and social factors which drive a willingness to protect these resources.

In contrast to Chipko where women have been perceived as taking the lead role in environmental actions, men in Dediapada and Valia spearheaded conservation activities. This raises questions about the usefulness of generalizing the relationship between either men or women and the environment. Below, we list four conditions which are necessary for mobilizing a community (whether men and/or women) to protect their common natural resources:

\subsection{Livelihood security}

The level of insecurity facing livelihoods is a primary determinant of the degree to which groups will be motivated to come together for action. A material objective located within a specific set of social relations motivated men in Bharuch to protect local forests. They had a long-term interest in conserving forest resources so that sustenance requirements could be met and thus their dependence on migration could be reduced. However, once men were assured of their short-term livelihoods being met from the combination of their PPRs and localCPRs, they were more willing to invest in forestconserving activities.

In Dediapada and Valia, men's migration was perceived as a temporary phenomena and since they had no other secure livelihoods to fall back on, their interest in pursing a secure village-based livelihood remained intact. At the same time, their private resources were underdeveloped due to a lack of investment and indebtedness. Their stakes in securing livelihoods within their villages were thus high.

\subsection{Security of land tenure}

Related to the issue of livelihoods is that of security of tenure and usufruct rights to land. Interest in protecting natural resources is closely tied to expectations of access to the benefits of forest guardianship. Confirmation by the Government of Gujarat of the JFM programme which granted usufruct rights to forest produce in Dediapada and Valia provided the major incentive for men's involvement in forest protection.

If women are assured usufruct rights to forest produce they will have a major stake in protecting local forests. Similarly, if men hold these rights, they will be similarly interested: '...villagers do not need to be told about the importance of the commons. They know it well and are willing to manage them but they must first be assured that the benefits will go to them and not to the government or a contractor. And they will gladly manage the commons jointly if they know that they will get a fair share' (Agarwal and Narain 1989: vi).

\subsection{Institutional support and VIs}

Most traditional institutions for managing common property resources were eroded or collapsed after the state took control of the forests. The presence of an enabling institution can catalyse village communities to adopt forest management and protection. Common interest groups, whether of mixed, male or female membership have been supported by the FD and NGOs in India under the JFM approach (Poffenberger 1990). The establishment of an institutional support system, through which diverse social groups can express their concerns, can enable both men and women to develop local initiatives for protecting their environment.

\footnotetext{
3 Men have played similar roles in other successful examples of JFM like those in Arabari and Chingra Mouza in West Bengal. See Poffenberger (undated).
} 
The disciplined use of natural resources is difficult to conceive without a management system which is acceptable to a village community as a whole. VIs play a significant role in mobilizing people with common interests. They can often see linkages between the different livelihood concerns of people, can incorporate different strategies to address the conflicting priorities within these, can engage in decision making about adopting incentives or fines relating to forest protection, and can oversee the distribution of the benefits of this work.

\subsection{Crisis management}

Communities tend to take action against environmental destruction only when it takes on alarming proportions and when a crisis situation is perceived. A crisis faced by members of a community can force them to work together to search for ways for restricting the damage and ensuring the security of local livelihoods.

The generalization that women, rather than men, will take the initiative to protect natural resources therefore prevents a more useful analysis of the process. The context within which women and men operate, as defined by their livelihoods, prevailing land tenure systems, the presence and quality of institutions and so on, are all critical in determining the nature, extent and sustainability of action by common interest groups. Thus a context-specific analysis is vital in understanding whether and why men, women or mixed communities come together to form common interest groups around natural resource conservation.

However, it is important to note that though these four conditions are necessary preconditions for a community to decide on protecting local natural resources, they are not sufficient for ensuring the long-term sustainability of conservation activities. When women or men alone take up this role, this can lead to disharmony in existing social relations and can thus make life more difficult for some members of the community. Joshi (1984), for example, describes the ordeal Chipko women faced within their households and villages and the price they had to pay in their own social lives while the movement was gaining international acclaim. Similar social conflict also followed in Dediapada and Valia. This emphasizes the importance of addressing conservation issues with both men and women and the need to understand the gender relations involved.

\section{WOMEN'S EXPERIENCES WITH REFORESTATION AND PROTECTION}

From the very outset, membership of the VIs supported by AKRSP was open to women. Two people per household, a woman and a man, were accepted for membership. Although women did become members in fairly large numbers, their motivation stemmed from an interest generating income from plantation work, something which was available to members only. However, women felt uneasy expressing their views in front of men, especially in public meetings. Eventually separate women's institutions were started to allow women to talk freely. However, it was difficult to envisage how women could be involved in the management of natural resources when resource ownership and control over decision making, at least in the 'public' spheres, were heavily biased towards men. For example, early attempts to engage women in nursery raising and, then, after 1990 to encourage women to open personal bank accounts into which their salaries could be paid had resulted in the appropriation of women's wages by male kin.

The issue of voluntary protection was discussed in a meeting at Sakwa village in August 1991. Local women were asked whether they would like to take over responsibility for protecting reforested land since men appeared to be disinterested in conservation activities. Women agreed readily to this proposal. This unexpected and strongly affirmative response from the women had an immediate impact on the men present at the meeting, who began to discuss the reasons why they had not been involved in forest protection. This resulted in a renewed resolve to participate in forest protection and fines formen'snon-participation were decided upon. Thus women's attempt to take control and 'show the men how to do it', was overruled by men who saw this as a threat to their control over women and over resources.

Once the Sakwa men had resumed voluntary protection, women reported that their willingness to take over forest protection had worked well as a threat and that it was convenient for them to let the men carry on with their forest duties. In this context, it can be argued that the Sakwa women had struck a 'patriarchal bargain'4 (see following page for footnote reference), when a mild threat of taking over male public space motivated local men to take community work more seriously. However, the alienation of women from the process of protection 
led to a number of problems, both within social relations and in terms of sustaining the environmental conservation efforts of men.

In November 1991, the VI in Pingot was conferred a prestigious award for environmental conservation. The village has over 400 hectares of public wastelands, of which 390 hectares had been reforested and protected by the VI. The system of voluntary protection had been near perfected by villagers and a workable system of rotations and schedules had been devised for day and night patrols. Heavy fines and penalties were imposed on defaulting members.

However, when the women in Pingot were asked to comment on the award and share their thoughts about the regenerated forest, they replied, 'What forest? We don't know anything about it now. We used to go to the forest to pick fuelwood but ever since the men have started protecting it they don't even allow us to look at it!' So what were the implications of their isolation? They drew a map on the ground showing what they meant. Since most of the 'forest' land in Pingot had been reforested and was being protected by the VI there were only two small plots left at the two extreme corners of the village where they could collect fuelwood. Since Pingot had a vast expanse of 'forest' land, there had been no dearth of dead wood earlier and women were able to collect enough fuelwood to meet their requirements without too much effort. They were now forced to take their daughters along with them, spending more than six hours a day and walking five times further than they used to, to collect the same quantity of fuelwood. A walk with the women to both sites revealed that there was virtually nothing left on the plot closer to the village and women were actually forced to dig the root stock.

The lessons from this experience were clear. The appearance of cohesive community participation, where men from nearly all the households had participated in protecting their forests, was, in fact, extremely deceptive. While local men had enthusiastically guarded the forests, women emerged as the absolute losers in the situation. The undermining of women's concerns and their limited bargaining power with men proved to be more harmful to the long-term sustainability of the forests and resulted in a great deal of frustration and personal hardship for women. Women's lack of input into the decision making process and the lack of attention to their existing user rights and access to the forest was going to drive them to destroy the remaining forest. It was also clear that without providing alternatives for cooking fuel, there would be increasing pressure on the fragile natural resource base. Clearly, options that make losers out of one group in society are not optimal and sustainable until the losers are given the choice of alternatives to make up for their losses.

\section{GENDER RELATIONS IN THE INTER- VILLAGE CONTEXT}

On a walk through the contiguous protected forests of Motiya and Sakwa villages, some AKRSP staff met a group of women from Sakwa walking back to their village with headloads of freshly cut wood. They were returning home having cut wood from forest protected by the VI in Motiya. They explained that they would not do such a thing in Sakwa itself since they were interested in letting their forest regenerate. Besides, thelush forest in Motiya was tempting since the only alternative was to walk several kilometres to the FD owned 'forest' where forest guards posed a constant threat to their gathering activities and personal safety. They added that women from Motiya were known to similarly meet their woodfuel requirements from the Sakwa forest.

Similar cases of tension between villages have surfaced ever since the barren lands started regenerating. People living in the adjoining villages of Mandala and Garda are now sworn enemies of each other. The Garda Forest Protection Committee, promoted by the FD, had been patrolling a part of their forest land in response to thefts of timber and bamboo by Mandala villagers. When confronted by the Garda patrols, Mandala men started sending women to the forest. Patriarchal ideology allows men to dominate over women in nearly all social fora, but physical confrontation with women from outside their own families or clans is forbidden. Devi Singh recalls that when, in 1990, Garda villagers complained to Mandala men about the activities of Mandala women, villagers reacted by burning $7000 \mathrm{pula}^{5}$ of stored fodder in Garda. The tension intensified and, in 1991, women from Mandala set fire to about 20-22 hectares of protected forest in Garda. When

${ }^{4}$ Kandiyoti (1988) uses the term 'patriarchal bargain' to describe the ${ }^{5}$ A bundle i.e. one pula $=15 \mathrm{~kg}$. strategies that women in a subordinated social position use to negotiate the best possible terms for themselves. 
Garda men reached the spot, the women accused them of rape.

Obviously, men in Mandala were using women to claim a share in what had been protected over the years by Garda people. These women were thus being used to operate a 'patriarchal bargain' against Garda men.

Pingot and Ambakhadi villages witnessed similar fiery scenes in 1991 when Pingot volunteers caught 14 men from Ambakhadi felling trees at night in Pingot protected forests. The men were marched about eight kms to the Range Forest Officer's (RFO) office where demands were made that the culprits be beaten up and fined heavily. As expected, Ambakhadi villagers retaliated by closing a track, heavily used by Pingot bullock carts, which ran through the village to the local market. Moreover, people from both villages were harassed and beaten up. The situation was finally diffused by the leaders of the two VIs. Mutually agreed fines and compromises were agreed upon. Som Bhai, chairman of the Pingot VI argued the following:

I am wondering what we [Pingot people] are gaining from protecting our forests so religiously? We don't allow anyone to enter our forests. If it continues like this, every village around Pingot will be our enemy. Then their relatives in other villages will become our enemies as well. At this rate our daughters in Pingot will never be able to get married. Who will want to marry an enemy's daughter?

It was clear that protection could not be practised in isolation by a village. It was not just an issue between men and women in a single village, but required negotiation between communities. Central to the process of forest protection are issues related to people's relations, both material and social, which spread far beyond the boundaries of a village. Unlike private property resources, common resources like forests encompass social relations which spread out over larger clans and neighbouring villages, a fact that has been by and large ignored in the GED literature ${ }^{6}$. Agarwal and Narain (1989: vi) refer to this as 'inter-settlement tensions'. These tensions exist and are likely to emerge strongly when protection is partial and not accepted by a range of villages sharing common access lands. The planning process,

${ }^{6}$ Most case studies in GED literature discuss gender relations as they operate with respect to PPRs, or the conflicts and complimentarities therefore, must at some stage conceive pan-village organizations or federations of contiguous villages, where people jointly decide priorities, protection, usufruct rights and management.

\section{CONCLUSION}

The process of common property natural resources management is a dynamic one requiring the assimilation of a multitude of interests held by distinct social groups within communities. Common property protection can not be achieved unless the livelihood concerns of a community are secure and local people have a stake in protecting natural resources. The security of usufruct rights is therefore of utmost importance if people, whether male or female, are to support a conservation programme.

However, for the long-term sustainability of environmental projects, people's commitment to forest protection can be short-lived unless the specific gender relations under which men and women interact with the environment are understood. Growing evidence now points to the fact that rural communities do not have a simple set of shared concerns (Rocheleau 1990; 1991a; Leach 1992; Leach and Fairhead 1992; and Fortmann and Bruce 1991). Indeed, men and women and other social groups may have both conflicting and complimentary interests in relation to natural resources. The question therefore is not whether it is men or women, who by any traditional cosmological view are seen as protectors or healers of the planet, but whether social relations as they stand changed in the present context are understood and considered while conceptualizing a community-based natural resources conservation programme. And this can best be achieved by ensuring that the concerns of various interest groups are situated, debated and finally integrated into the planning process.

Local institutions can play a significant role in ensuring the process of participatory planning takes account of varied interests. However, special efforts will be needed to enable women to participate on an equal footing in such fora, since traditional power structures within social relations provide them with little bargaining space. More work needs to be done on finding ways in which women can institutionalize the few bargaining strengths they have, and in working out the leverages and incen-

between different social groups that operate within a household or a village community. See Leach 1992; Rocheleau $1991 \mathrm{~b}$. 
tives that would ensure a voice and space for the most marginalized groups within decision making processes.

Social relations become even more complex in the case of common property resources management since they have the potential of becoming sites of inter-community tensions over issues like use rights. Hence for the long-term sustainability of natural resources, the formation of pan-village organizations which take into account the complex gender and social relations within and among the village communities within their purview is of major importance.

\section{REFERENCES}

Agarwal, A., and Narain, S., 1989, Towards Green Villages, New Delhi: CSE

Centre for Science and Environment (CSE), 1985, The State of India's Environment, 1984-85: The Second Citizen's Report, New Delhi: CSE

Dankelman, I., and Davidson, J., 1993, (first edition 1988), Women and Environment in the Third World, London: Earthscan/IUCN

Fortmann, L., and Bruce, J., 1991, 'You've got to know who controls the land and trees people use: gender tenure and the environment', paper presented at the SIDA workshop on Gender and the Environment, Stockholm, Sweden

Joshi, G., 1984, 'Protecting the sources of community life: slandered by the community in return' in M. Kishwar and Vanita, R., (eds), In Search of Answers, London: Zed Books

Kandiyoti, D., 1988, 'Bargaining with patriarchy', Gender and Society Vol 2 No 3

Leach, M.,1992, 'Gender and the environment: traps and opportunities', Development in Practice Vol 2 No 1:12-22

Leach, M., and Fairhead, J., 1992, 'Social differentiation in resource access, use and control: implications for rural development policy in Kissidougou prefecture', Working Paper No 2, Guinea, W. Africa: COLA
Plant, J., (ed.), 1989, Healing the Wounds: the Promise of Ecofeminism, Philadelphia: New Society Publishers

Poffenberger, M., undated, 'Joint forest management in West Bengal: the process of agency change', New Delhi: Ford Foundation

Poffenberger, M., 1990, 'Joint management of forest lands: experiences from South Asia', New Delhi: Ford Foundation

Rocheleau, D., 1990, 'Gender complementarity and conflict in sustainable forestry development: a multiple user approach', paper presented to IUFRO World Congress Quinquennial, Montreal

_- 1991a, Whose common future? A land user approach to gendered rights and responsibilities in rural landscapes', paper presented at the SIDA workshop on Gender and the Environment, Stockholm, Sweden

-1991b,. 'Gender, ecology, and the science of survival: stories and lessons from Kenya', Agriculture and Human Values, winter - spring issue

Shah, M. K., 1993, 'Impact of technological change in agriculture: women's voices from a tribal village in South Gujarat, India', unpublished paper, Brighton: IDS

Shiva,V., 1988, Staying Alive, London: Zed Books

\section{REVIEW BOOKS RECEIVED}

Abbas Rashid and Farida Shaheed, 'Pakistan: ethno-politics and contending elites', UNAISD Discussion Paper 45, Geneva: UNRISD, June 1993

Inter-Regional Participatory Upland Conservation and Development Project Consultant Reports 2 to 4, Quetta, Pakistan: Food and Agriculture

Organization of the United Nations, 1993

U. Kalpagam, Labour and Gender: Survival in Urban India, New Delhi/Thousand Oaks/London: Sage Publications, 1994

Charles M. Becker et al., Beyond Urban Bias in Africa: Urbanization in an Era of Structural Adjustment, New Hampshire: Heinemann, and James Currey, London, 1994
'Poultry raising, egg production', Inter-Regional Participatory Upland Conservation and Development Project Working Paper 1, Quetta, Pakistan: Food and Agriculture Organization of the United Nations, 1994

K. C. Alexander, The Process of Development of Societies, New Delhi/Thousand Oaks/London: Sage Publications, 1994

Ralph R. Premdas, 'Ethnicity and development: the cas of Fij', UNRISD Discussion Paper 46, Geneva: UNRISD, October 1993

Hamish Main and Stephen Wyn Williams (eds), Environment and Housing in Third World Cities, Chichester: John Wiley and Sons, 1994 